\title{
Study of columnar aerosol size distribution in Hong Kong
}

\author{
X. Yang and M. Wenig \\ Laboratory for Atmospheric Research, Department of Physics and Materials Science, City University of Hong Kong, \\ Hong Kong, China
}

Received: 27 February 2009 - Published in Atmos. Chem. Phys. Discuss.: 30 March 2009

Revised: 10 August 2009 - Accepted: 17 August 2009 - Published: 31 August 2009

\begin{abstract}
This paper presents studies on columnar aerosol optical properties in Hong Kong with focus on aerosol volume size distribution, which helps understand local aerosol properties, variation, hygroscopic growth and coagulation. Long-term ground measurements in the wet season in the years of 2002, 2003, 2004 and 2008 have been performed using a sun-sky radiometer. Data validation made using MODIS and local AERONET shows agreement. A bimodal size distribution is found with the fine mode centering at $\sim 0.2 \mu \mathrm{m}$ and coarse mode centering at $\sim 3 \mu \mathrm{m}$ respectively. The fine and coarse mode have close volume concentrations of nearly $50 \%$ fraction in composing local aerosols. Intercomparison of different years shows similar aerosol properties while a small increase of fine mode aerosol could be observed. A systematic shift of size distribution parameters is observed with different atmospheric conditions, where higher aerosol loadings and Angstrom exponent correspond to more fine mode aerosols. The fine mode is found to be more closely correlated with this shift than the coarse mode. A higher fine mode volume fraction and smaller median fine radius correspond to a larger Angstrom exponent. The fine mode aerosol hygroscopic growth is one of the main mechanisms for such systematic shifting. A third mode centering at $\sim 1-2 \mu \mathrm{m}$ could be discovered under high aerosol loading and high fine mode aerosol conditions. It becomes more pronounced with high aerosol optical depth and larger Angstrom exponent. Investigation of its variation with corresponding optical parameters and correlation with atmospheric conditions appears to support the hypothesis that it is mainly due to the fine mode aerosol hygroscopic growth and coagulation rather than the contribution from the coarse mode. While the very humid environment facilitates the aerosol hygroscopic growth, aerosol coagulation might further produce
\end{abstract}

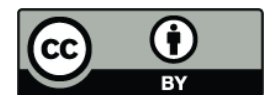

Correspondence to: $\mathrm{X}$. Yang (xunyang@cityu.edu.hk) larger aerosols under high fine aerosol conditions. The continental outflow with transported aging aerosols and biomass burning might have also contributed to this additional mode.

\section{Introduction}

Aerosols play an important role on Earth's radiation budget due to their scattering and absorbing capability and indirectly serving as the cloud nuclei. Aerosols differ in terms of their physical and chemical properties as well as their sources. Aerosol concentrations and optical properties are one of the largest uncertainties in current assessments of climate change (Intergovernmental Panel on Climate Change, 2007).

Aerosol size properties are one of the most important information for both modeling and experiments. Aerosol size information is critical for studying radiative transfer and model studies have shown its size distribution effect might overweigh some other aerosol properties like the mixing type and vertical profile (Schuster et al., 2006; Tang, 1996). Knowing aerosol size distribution is useful to distinguish anthropogenic aerosols from urban and biomass burning and natural aerosols like sea salt and dust. Such discrimination is important since their effect on the Earth's radiation budget depend on the aerosol type (Andreae, 2001) and also helps aerosol source tracing. Furthermore, the estimation of anthropogenic aerosols using satellite measurements is based on the assumption that man-made aerosols are generally from fine mode aerosols of small radius (submicron) while natural aerosols are usually from coarse aerosols (supermicron) (Kaufman et al., 2002, 2005). Ground measurements allow for estimation of fine and coarse aerosol volume fraction (Eck et al., 2005; Kaufman et al., 2001; Smirnov et al., 2003) as well as their respective contributions to other optical properties like the aerosol optical depth (Dubovik and King, 2000; O'Neill et al., 2003), and comparison of fine and coarse mode aerosol contributions from

Published by Copernicus Publications on behalf of the European Geosciences Union. 


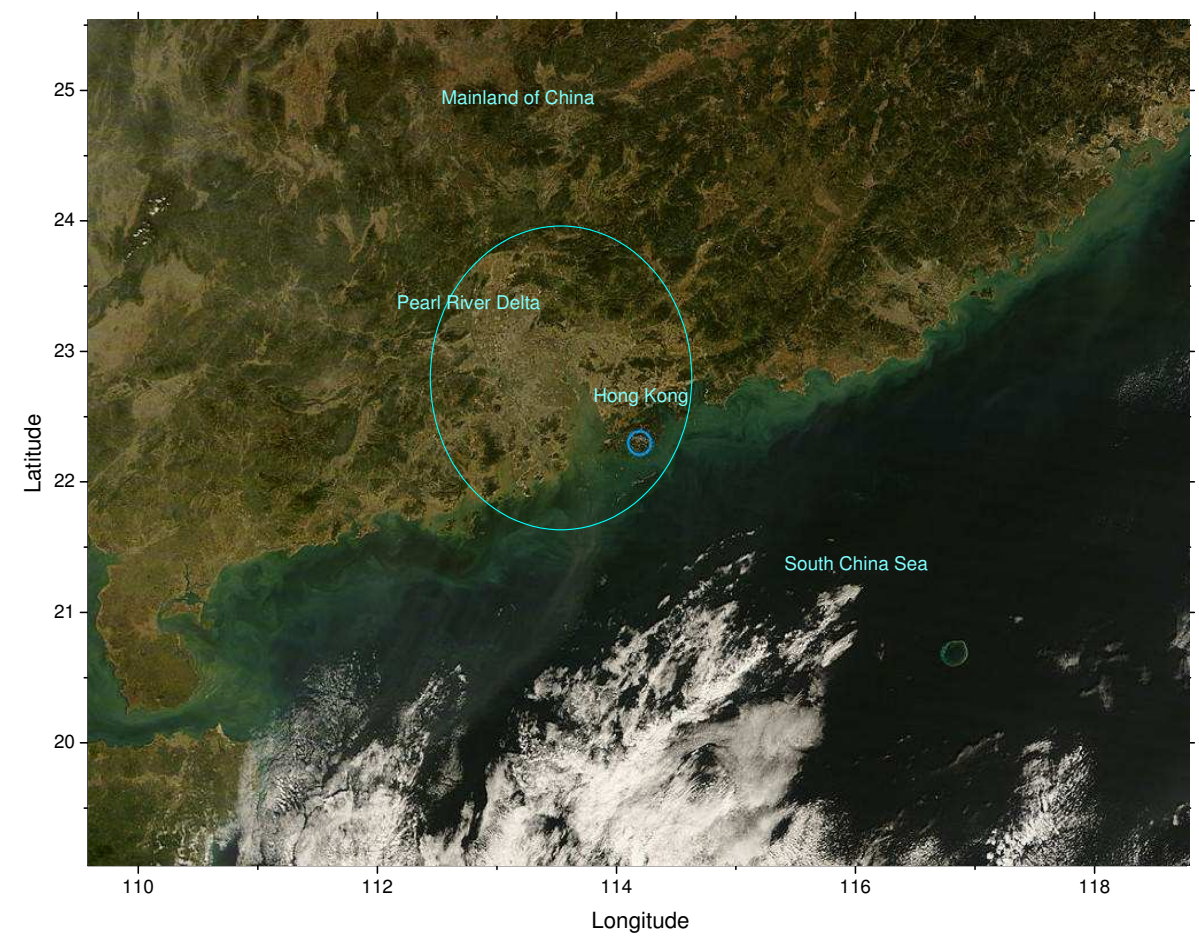

Fig. 1. Satellite view of Hong Kong and the Pearl River Delta region from MODIS Terra.

satellite and ground-based have been widely studied and validated (Kleidman et al., 2005). Because continuously groundbased measurements using sun-sky radiometers serves as one of the most accurate methods for studying columnar aerosol properties, networks have been built up covering worldwide sites like the Aerosol Robotic Network (AERONET) (Holben et al., 1998, 2001). The retrieval of aerosol size distribution together with aerosol optical depth (AOD) and Angstrom exponent $(\alpha)$ from such sun-sky radiometer measurements are of high accuracy, whereas the retrieval of other aerosol optical parameters such as the single scattering albedo, real part and imaginary part of refractive index is with larger errors and has more restrictions like requiring a high aerosol loading (Dubovik et al., 2002; Dubovik and King, 2000).

The aerosol size distributions are useful indicators to investigate the aerosol's evolution process such as its hygroscopic growth, coagulation and aging. Aerosol size distrbutions are also useful indicators of the sources and sinks. Studies of biomass burning aerosols in Africa (Eck et al., 2003b; Reid et al., 1999, 1998) and Latin America (Eck et al., 2003a; Reid et al., 1998, 1999) show a systematic shift of aerosol size distribution parameters, where increasing fine mode aerosol volume fractions and shift in median aerosol radius under higher aerosol loadings are found. The aerosol aging and hygroscopic growth are considered as possible causes. The size distribution of urban-industrial aerosols shows the appearance of an additional third mode between and fine and coarse modes, which is considered as the consequence of aerosol hygroscopic growth under heavy loading and humid conditions (Dubovik et al., 2002; Singh et al., 2004). The aerosol size distributions vary under different atmospheric conditions like a light or heavy aerosol loading. The aerosol size distributions under the predominately fine or coarse particles conditions have been studied using the Angstrom exponent as a discriminator, where a large Angstrom exponent indicates more fine mode aerosol events (Eck et al., 2008; Kaufman et al., 2001; Smirnov et al., 2003). The variation of aerosol size distribution under different aerosol loadings discriminated by aerosol optical depth has been studied at urban (Dubovik et al., 2002), desert (Eck et al., 2005), forest (Schafer et al., 2008) and coastal (Smirnov et al., 2003) sites.

Hong Kong is a coastal city located in the Pearl River Delta (PRD) region. The PRD is one of the largest urban-industrial regions of China (Fig. 1). The Pearl River Delta Region has a total land area of $42794 \mathrm{~km}^{2}$ with a population of over 50 million (Hong Kong, $\sim 1100 \mathrm{~km}^{2}, 6.8$ million). Whatever measurements are taken, the industrial pollutions and anthropogenic aerosols seem to increase in recent years. However, the local aerosol constituents and their sources have not yet been thoroughly understood mainly due to Hong Kong's special geographical location and complex atmospheric conditions. In addition to local emissions, both the continental outflow and the South China Sea affect local environment. Cooperative campaigns and local measurements demonstrate 
the influence of continental outflows on local air conditions (Huebert et al., 2003; Wang et al., 2003). Organic and fine mode aerosols like the $\mathrm{PM}_{2.5}$ are found to be of high concentrations, indicating local anthropogenic emissions and continental outflows (Cohen et al., 2004). The biomass burning aerosols from the mainland and Southeast Asia countries also have an impact on the local environment (Chan et al., 2003, 2000; Heald et al., 2003). The maritime aerosols like the sea salt is also found to have a high fraction in composing the ambient particulates (Cohen et al., 2004; Zheng et al., 2008). The oceanic environment especially the monsoon from the ocean in summer and fall result in high humidity in Hong Kong. Such humid environment could facilitate the aerosol evolution process through hygroscopic growth as have been found in many industrial and coastal areas (Dubovik et al., 2002; Eck et al., 2003b; Reid et al., 1999; Singh et al., 2004). In this paper, we present the observation results of aerosol optical properties with focus on its size properties from August to November in four years. We analyze aerosol's size distribution, variation and the underlying mechanism.

\section{Data and inversion algorithm}

\subsection{Instrument and site}

A sun-sky radiometer has been installed in the main campus of City University of Hong Kong (CityU, $22.34^{\circ} \mathrm{N}$, $114.17^{\circ} \mathrm{E}$ ) locating in the urban center of Hong Kong. We use a POM-01 sun-sky radiometer, which has been widely used for measuring atmospheric aerosols (Carmine et al., 2005; Kaufman et al., 1994; Kim et al., 2004; Nakajima et al., 2003). It consists of a sun-sky spectral radiometer, a sun sensor, a sun-tracking unit and a PC for data logging. It has seven spectral channels with centered wavelengths at 315 , $400,500,675,870,940$, and $1020 \mathrm{~nm}$ respectively. The filter's half-bandwidth is $3 \mathrm{~nm}$ for the 315 wavelength and less than $10 \mathrm{~nm}$ for the other wavelengths. The 315 and $940 \mathrm{~nm}$ channels are used for deriving the ozone concentration and precipitable water column amounts, respectively, while the other five wavelengths are used for measuring aerosols.

The sun-sky radiometer starts measurements by tracking the sun position and measuring direct and diffuse solar radiance by scanning in either of two modes, the almucantar and principle scanning. The almucantar scanning is changing the almucantar angle from $0^{\circ}$ to $180^{\circ}$ on the right or left sides with respect to the sun position when the zenith angle remains the same, while the principle scanning is rotating the zenith angle with fixed almucantar angle. When zenith angle is smaller than $15^{\circ}$, the principal scanning is performed, otherwise the almucantar scanning is taken. The sky radiometer starts running every day when the air mass is larger than 3 . The measurement interval is typically $10 \mathrm{~min}$. More details about the instrument and working principle can be found in papers by Nakajima et al. (1996) and Tonna et al. (1995).
Table 1. Monthly mean relative humidity in 2002, 2003, 2004 and 2008.

\begin{tabular}{lllll}
\hline RH $(\%)$ & 2002 & 2003 & 2004 & 2008 \\
\hline Jan & 75 & 71 & 73 & 75 \\
Feb & 77 & 82 & 79 & 72 \\
Mar & 81 & 82 & 80 & 76 \\
Apr & 82 & 83 & 83 & 85 \\
May & 81 & 81 & 82 & 83 \\
Jun & 80 & 81 & 78 & 88 \\
Jul & 82 & 76 & 82 & 82 \\
Aug & 81 & 81 & 82 & 79 \\
Sep & 80 & 81 & 77 & 75 \\
Oct & 77 & 71 & 64 & 77 \\
Nov & 72 & 75 & 73 & 65 \\
Dec & 80 & 65 & 70 & 63 \\
\hline
\end{tabular}

The sky radiometer commenced running in 2002 and continued measurements till early 2005. Afterwards the measurements were interrupted due to maintenance. It was reinstalled in the site in June 2008 and has been taking measurements from July after nearly one-month setting and adjusting. For intercomparison, the data presented here are from July to November in the years of 2002, 2003, 2004 and 2008. Table 1 presents the monthly mean relative humidity in the four years recorded by the Hong Kong Observatory. The absolute variation of the environment relative humidity is insignificant with a mean value larger than $70 \%$ and a minimum value larger than $60 \%$. The local meteorological conditions at this period are greatly affected by the southerly monsoon usually in June and July and the north-easterly monsoon from August to November. The sun-sky radiometer would stop working when it is rainy or heavy cloudy and thus there are usually no data for the severe whether conditions like a tropical cyclone with heavy rainfall. Moreover, the inversion algorithm would further screen out more cloud-contaminated data as we will introduce in the next part.

\subsection{Data inversion}

The data inversion is implemented using the algorithm based on a multiple scattering radiation transfer model, where the atmosphere is assumed to be two parallel planes (Nakajima et al., 1996; Boi et al., 1999). The retrieved aerosol optical properties include the aerosol optical depth, size distribution, Angstrom coefficient, single scattering albedo, refractive index and phase function (Carmine et al., 2005; Kaufman et al., 1994). An important feature of the inversion algorithm is that an improved Langley plot method has been used to calculate the instrumental calibration constant $V_{0}$ (Boi et al., 1999; Campanelli et al., 2007; Nakajima et al., 1996) in the equation, $V=V_{0} \exp \left(-m_{0} \tau\right)$, where $V, m_{0}$ and $\tau$ represent the measured radiance, air mass factor and optical depth respectively. In the normal Langley method, the calibration 
Table 2. Average aerosol optical properties in the years of 2002, 2003, 2004 and 2008.

\begin{tabular}{lllll}
\hline & 2002 & 2003 & 2004 & 2008 \\
\hline Fine mode volume fraction $(\%)$ & 45.61 & 47.16 & 49.12 & 49.17 \\
$r_{f}(\mu \mathrm{m})$ & 0.19 & 0.17 & 0.18 & 0.19 \\
$r_{c}(\mu \mathrm{m})$ & 2.65 & 2.78 & 2.78 & 2.71 \\
$r_{V}(\mu \mathrm{m})$ & 0.84 & 0.77 & 0.77 & 0.75 \\
$C_{f}\left(\mu \mathrm{m}^{3} \mu \mathrm{m}^{-2}\right)$ & 0.073 & 0.072 & 0.096 & 0.084 \\
$C_{c}\left(\mu \mathrm{m}^{3} \mu \mathrm{m}^{-2}\right)$ & 0.089 & 0.085 & 0.103 & 0.086 \\
$C_{V}\left(\mu \mathrm{m}^{3} \mu \mathrm{m}^{-2}\right)$ & 0.162 & 0.157 & 0.198 & 0.169 \\
$\sigma_{f}\left(\mu \mathrm{m}^{2}\right)$ & 0.52 & 0.56 & 0.52 & 0.50 \\
$\sigma_{c}(\mu \mathrm{m})$ & 0.78 & 0.77 & 0.78 & 0.81 \\
$\sigma_{V}(\mu \mathrm{m})$ & 1.45 & 1.53 & 1.48 & 1.47 \\
$\mathrm{AOD}$ & 0.57 & 0.52 & 0.71 & 0.55 \\
$\alpha$ & 1.32 & 1.39 & 1.39 & 1.33 \\
\hline
\end{tabular}
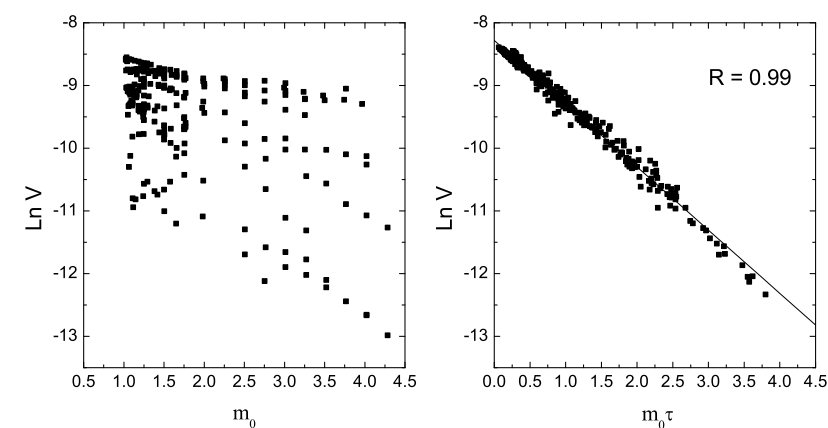

Fig. 2. The Langley plots from the normal (left plot) and improved (right plot) methods at $500 \mathrm{~nm}$ in 2008 .

constant is obtained by performing a logarithmic plot of the air mass versus measured direct solar radiation when assuming that the aerosol optical depth remains the same during the whole measurement process. However, this assumption rarely exists. The improved Langley plot method in the inversion algorithm is making use of diffuse radiation and running the inversion procedure to estimate the aerosol optical depth. Then the estimated aerosol optical depth is used in the Langley plot for calculating the calibration constant. The calibration constant for each year has been calculated separately. Figure 2 shows the comparison of the two methods for data of 2008 at $500 \mathrm{~nm}$ channel.

A 5\% threshold is set for the inversion that requires the reconstructed radiance from inversion has a maximum 5\% uncertainty with the measured radiance, which come from the improved Langley plot method and the inversion algorithm respectively. Hong Kong is quite cloudy and the monthly average cloud amount in this season of the year is $\sim 64 \%$ according to the Hong Kong Observatory records. This has a significant impact on the retrieval process and has to be considered when interpreting results. Therefore a cloud screen- ing procedure used in the AERONET (Smirnov et al., 2000) has been applied. It checks the stability of aerosol optical depth and identifies those extensive temporal variations as cloud contamination. Furthermore, a minimum measurement number for a specific almucantar scanning range is required in AERONET inversion for data qualification. Therefore we only use data with at least 1 measurement in each of the scattering angle interval, $3^{\circ}-10^{\circ}, 10^{\circ}-30^{\circ}, 30^{\circ}-80^{\circ}$ and larger than $80^{\circ}$, respectively. Concerning the retrieved aerosol size distribution, the error for small and large radius range is usually larger than that at the middle radius range. the retrieval error is estimated to Dubovik et al. (2002) estimated that the retrieval error is to be under $10 \%$ of the maxima and might increase up to $35 \%$ for the intermidiate size range $(0.1 \leq r \leq 0.7 \mu \mathrm{m})$ while the error might rise up to 80 $100 \%$ at the edges $(0.05 \leq r<0.1 \mu \mathrm{m}$, and $0.1<r \leq 15 \mu \mathrm{m})$. Nakajima et al. (1996) estimated that a within $20 \%$ precision for the middle range and $35-100 \%$ at the edges. To filter out anomaly data with extremely high volume values for size distribution at small radius $(r<0.03 \mu \mathrm{m})$ and large radius $(r>7 \mu \mathrm{m})$, a threshold is added that requires the mean volume values at the two ranges to be smaller than the mean value of the whole size distribution spectra. The experimental data show that the values for normal size distribution are usually with the maximum value smaller than $0.1 \mu \mathrm{m}^{3} \mu \mathrm{m}^{-2}$, therefore those anomaly ones with absolute values 100 times larger (exceeding $10 \mu \mathrm{m}^{3} \mu \mathrm{m}^{-2}$ ) are filtered out. Those outliers are typically caused by cloud contamination.

\section{Results}

\subsection{Intercomparison with MODIS and AERONET}

Figure 3 shows the retrieved aerosol optical depth from the CityU sun-sky radiometer in comparison with AODs from the Moderate Resolution Imaging Spectroradiometer 

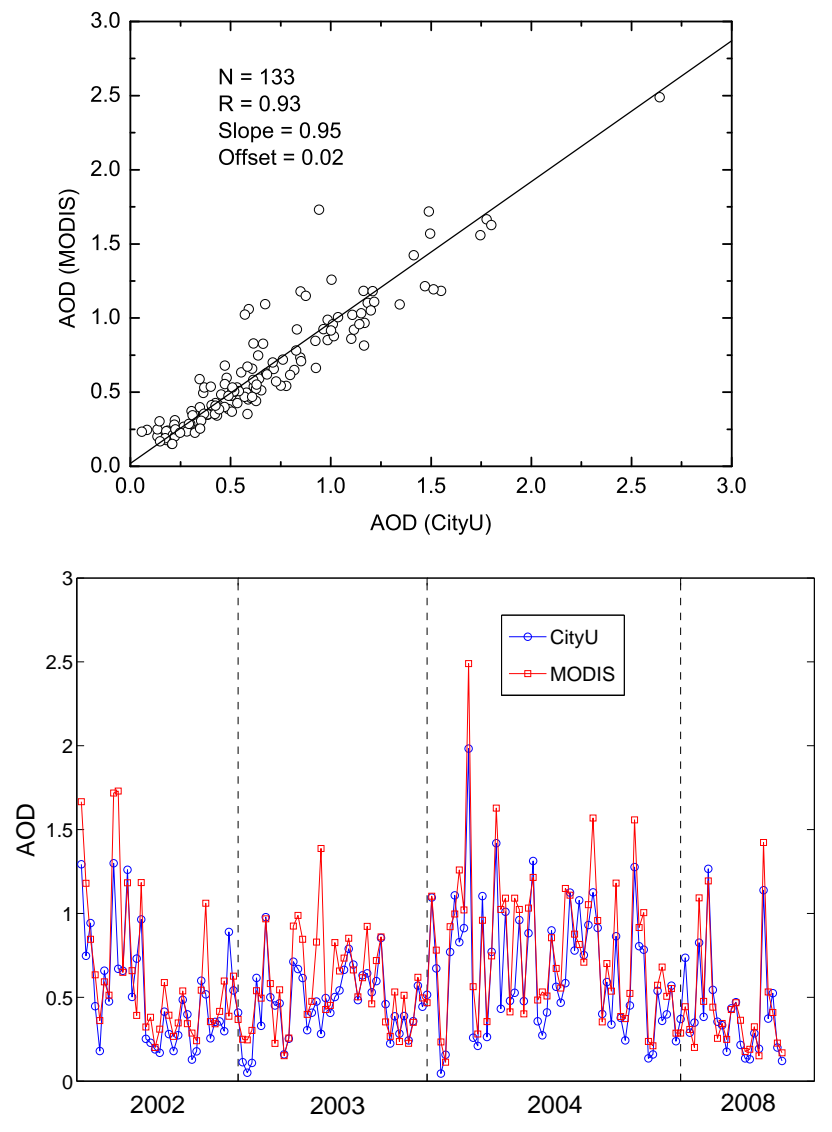

Fig. 3. Intercomparison of AODs from CityU and MODIS terra (133 coincident days) in terms of scattergrams (upper plot) and time series (lower plot).

(MODIS) launched aboard Terra (in the late 1999) and Aqua (in the early 2002) (Kaufman et al., 1997; Remer et al., 2005). With 36-wavelength channels and a orbit height of $\sim 700 \mathrm{~km}$, MODIS provides global aerosol distribution information like the aerosol optical depth. The latest version 5 data collection (C005) (Levy et al., 2007) in Level 2 products have been used for comparison. It is granule-based dataset of 5 -min segment, $10 \times 10 \mathrm{~km}$ pixel and $0.5^{\circ} \times 0.5^{\circ}$ scale $(\mathrm{Chu}$ et al., 2003; Ichoku et al., 2002; Remer et al., 2005)

For the comparison, we use the MODIS AODs of Terra at $550 \mathrm{~nm}$ wavelength from C005 collection. Terra passes through Hong Kong at $\sim 11: 00$ a.m. local time. The mean AOD from a $50 \times 50 \mathrm{~km}$ scanning region with center close to CityU campus has been used. The MODIS AODs are compared with the sun-sky radiometer mean AODs 2$\mathrm{h}$ before and after the Terra passing. There are a total of 133 coincident days. The AODs at $500 \mathrm{~nm}$ wavelength from the sun-sky radiometer have been converted to AODs at $550 \mathrm{~nm}$ wavelength using Angstrom exponent calculated at $400-870 \mathrm{~nm}$. The Angstrom exponent is calculated by a linear least squares fitting of the Angstrom

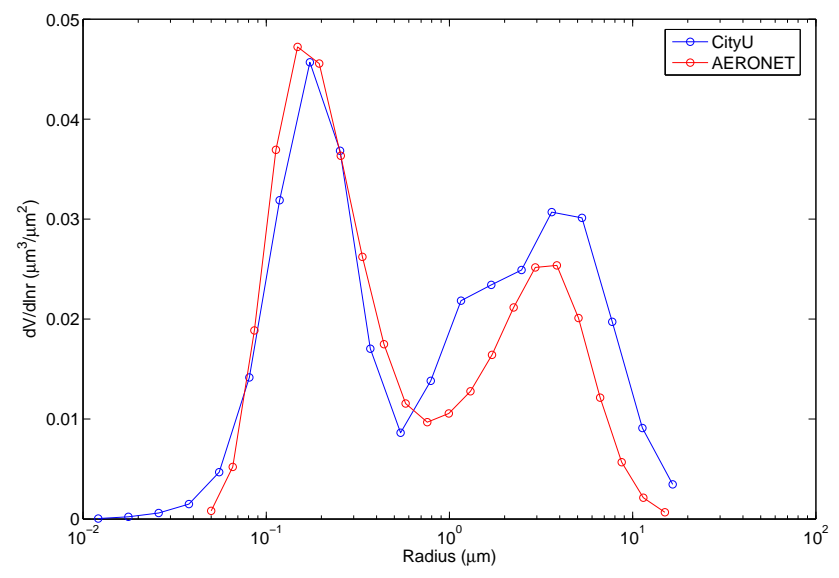

Fig. 4. Intercomparison of average aerosol size distributions of CityU and AERONET from October to November of 2008 (22 concident days).

equation from 400 to $870 \mathrm{~nm}$ wavelengths, where $\alpha$ is the Angstrom exponent and $\tau_{a}(\lambda)$ denotes the aerosol optical depth at wavelength $\lambda$ (Angstrom, 1929). The two AODs have a total least squares linear regression relationship as, $\mathrm{AOD}_{\mathrm{MODIS}}=\mathrm{AOD}_{\mathrm{HK}} \times 0.95+0.02$, and a correlation coefficient $R$ of 0.93 . More coincident data could be included when using sun-sky radiometer AODs within a larger time interval. For instance, there are a total of 153 days when comparing the daily mean sun-sky radiometer with MODIS, which has correlation coefficient of 0.86 and slope of 0.92 . The single pixel MODIS AOD data closed to the measuring site is very limited because of cloud contamination. There are a total of 25 coincident days for the sun-sky radiometer and MODIS AODs and 26 coincident days for the MODIS mean and single pixel data during the studied period. The linear regression of single-pixel and mean-pixel AODs has a slope of 0.91 , indicating larger AOD values from the singlepixel, which is close to CityU site.

Figure 4 shows the comparison of retrieved aerosol size distributions from CityU and a local AERONET site. The local AERONET site is located at Polytechnic University of Hong Kong (PolyU), which is $\sim 13 \mathrm{~km}$ away in the south and is also located in the urban area. The data from AERONET are the level 1.5 retrieval data after applying the cloud screening procedure mentioned above. The size distributions are averaged from daily mean size distributions from total $22 \mathrm{co-}$ incident days in October and November of 2008 since there are no data from local AERONET in July to September, and the relative humidity is relatively lower in October and November. The local AERONET site provides data from late 2005 and there are only size distribution data from October in 2008. The difference of the two retrieved size distributions is due to the instrument, criteria for data qualification, the inversion algorithm and the site's atmospheric conditions. 
The sun-sky radiometer in AERONET is a Cimel radiometer. For almucantar scanning, it takes three measurements at each scattering angle to restrict temporarily atmospheric variation due to clouds or plumes. Before applying the data inversion, a more restricted criterion is used in AERONET. For instance, the minimum measurement number are 2, 5, 4 and 3 for scattering angle bins of $3.2^{\circ}-6.0^{\circ}, 6.0^{\circ}-30^{\circ}, 30^{\circ}-80^{\circ}$ and larger than $80^{\circ}$ respectively (Dubovik et al., 2002). Therefore there are less number of retrieved data from AERONET. The daily average data numbers of AERONET in Fig. 4 is 3 , while the actual daily average measurement numbers are 20 according to the measured AOD numbers. Actually most of the measurement data are filtered out without retrieving aerosol optical properties like the size distribution. Thus we use a slightly lower filtering threshold as mentioned above so that more data can be analyzed. Concerning the inversion algorithm difference, studies have shown general agreement (Highwood et al., 2003). The different site locations result in difference mainly due to the different cloud influence, therefore the daily average size distributions are not from the exact data at the same hour or minute after cloud screening. The Hong Kong's high cloud amount further enhances such difference. With consideration to all of these factors, the intercomparison of the two size distribution agrees well with each other. Concerning the uncertainties, the middle range $(0.1 \leq r \leq 7 \mu \mathrm{m})$ of aerosol size distribution is generally with less uncertainty than the edges $(0.05 \leq r \leq 0.1 \mu \mathrm{m}$ and $7 \leq r \leq 15 \mu \mathrm{m})$, i.e., The retrieval errors might rise up to $80 \%$ to $100 \%$ at the edges, while it does not exceed $10 \%$ in the maxima and might rise up to $35 \%$ for the minima in the middle range (Dubovik et al., 2002; Dubovik and King, 2000).

\subsection{Annual size distribution and corresponding aerosol optical properties}

The annual mean aerosol volume size distributions of each year are shown in Fig. 5. There are 75, 86, 104 and 55 days for each year. A bimodal structure is observed. The fine and coarse modes can be separated by a radius value of $\sim 0.6 \mu \mathrm{m}$. The bimodal lognormal structure of aerosol size distribution has been found worldwide and can be described by

$$
\frac{d V(r)}{d \ln r}=\sum_{i=1}^{2} \frac{C_{V, i}}{\sqrt{2 \pi} \sigma_{i}} \exp \left[-\frac{\left(\ln r-\ln r_{V, i}\right)^{2}}{2 \sigma_{i}^{2}}\right]
$$

where $C_{V}$ is the volume concentrations, $r_{V}$ is the volume median size and $\sigma$ is the geometric standard deviation, and they can be calculated by the following equations:

$$
\begin{aligned}
& \ln r_{V}=\frac{\int_{r_{\min }}^{r_{\max }} \ln r \frac{d V(r)}{d \ln r} d \ln r}{\int_{r_{\min }}^{r_{\max }} \frac{d V(r)}{d \ln r} d \ln r} \\
& \sigma_{V}=\sqrt{\frac{\int_{r_{\min }}^{r_{\max }}\left(\ln r-\ln r_{V}\right)^{2} \frac{d V(r)}{d \ln r} d \ln r}{\int_{r_{\min }}^{r_{\max }} \frac{d V(r)}{d \ln r} d \ln r}}
\end{aligned}
$$

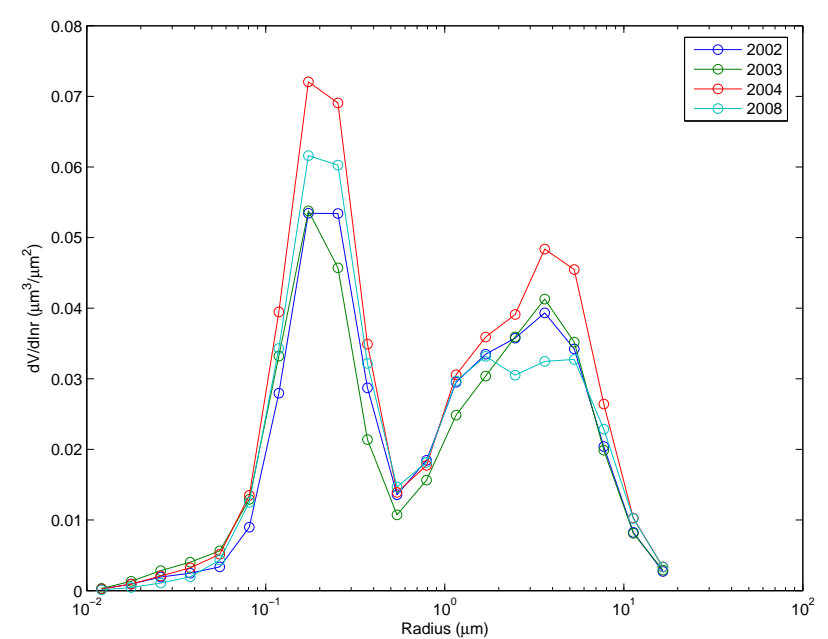

Fig. 5. Average aerosol size distributions in 2002, 2003, 2004 and 2008 respectively.

$C_{V}=\int_{r_{\min }}^{r_{\max }} \frac{d V(r)}{d \ln r} d \ln r$

Where $r_{\min }$ and $r_{\max }$ denote the radius ranges for corresponding modes. Dubovik et al. (2002) studied the worldwide aerosol size distribution from different AERONET sites and used the boundary radius $0.6 \mu \mathrm{m}$ for discriminating the fine and coarse modes. Investigation of aerosols in central eastern Asia also shows bimodal size distribution and the value $0.6 \mu \mathrm{m}$ is used to separate fine and coarse mode (Eck et al., 2005). The urban-industrial aerosols in northern India is also characterized by the fine and coarse modes with $0.6 \mu \mathrm{m}$ as the boundary radius (Singh et al., 2004). A more detailed description of the size distribution information as well as other aerosol optical properties is presented in Table 1 , where the volume median radii, volume concentrations, geometric standard deviations and the subscript we denote the aerosol type for fine, coarse and the whole modes are denoted by $C_{f}, C_{c}$ and $C_{V}, r_{f}, r_{c}$ and $r_{V}, \sigma_{f}, \sigma_{c}$ and $\sigma_{V}$ respectively. The fine mode and coarse mode volume fractions are the ratio of their volume concentration to the total volume concentration, i.e., $C_{f} / C_{V}$ and $C_{c} / C_{V}$, respectively.

The bimodal size distribution in Hong Kong has more or less the same volume fraction for the fine and coarse modes. The annual average fine mode volume fraction is a little bit smaller and close to $50 \%$. The fine mode volume fraction increases gradually from $45.61 \%$ to $49.17 \%$ in the four years. The median radius decrease from 0.84 to $0.75 \mu \mathrm{m}$ from 2002 to 2008. All of the aerosol volume concentrations including the fine, coarse and the whole mode have the largest values, $0.096,0.103$ and $0.198 \mu \mathrm{m}^{3} \mu \mathrm{m}^{-2}$ in 2004 and the smallest values, $0.072,0.085$ and $0.157 \mu \mathrm{m}^{3} \mu \mathrm{m}^{-2}$ in 2003. Correspondingly, the maximum and minimum annual AODs are found to be 0.71 in 2004 and 0.52 in 2003 . The fine mode 

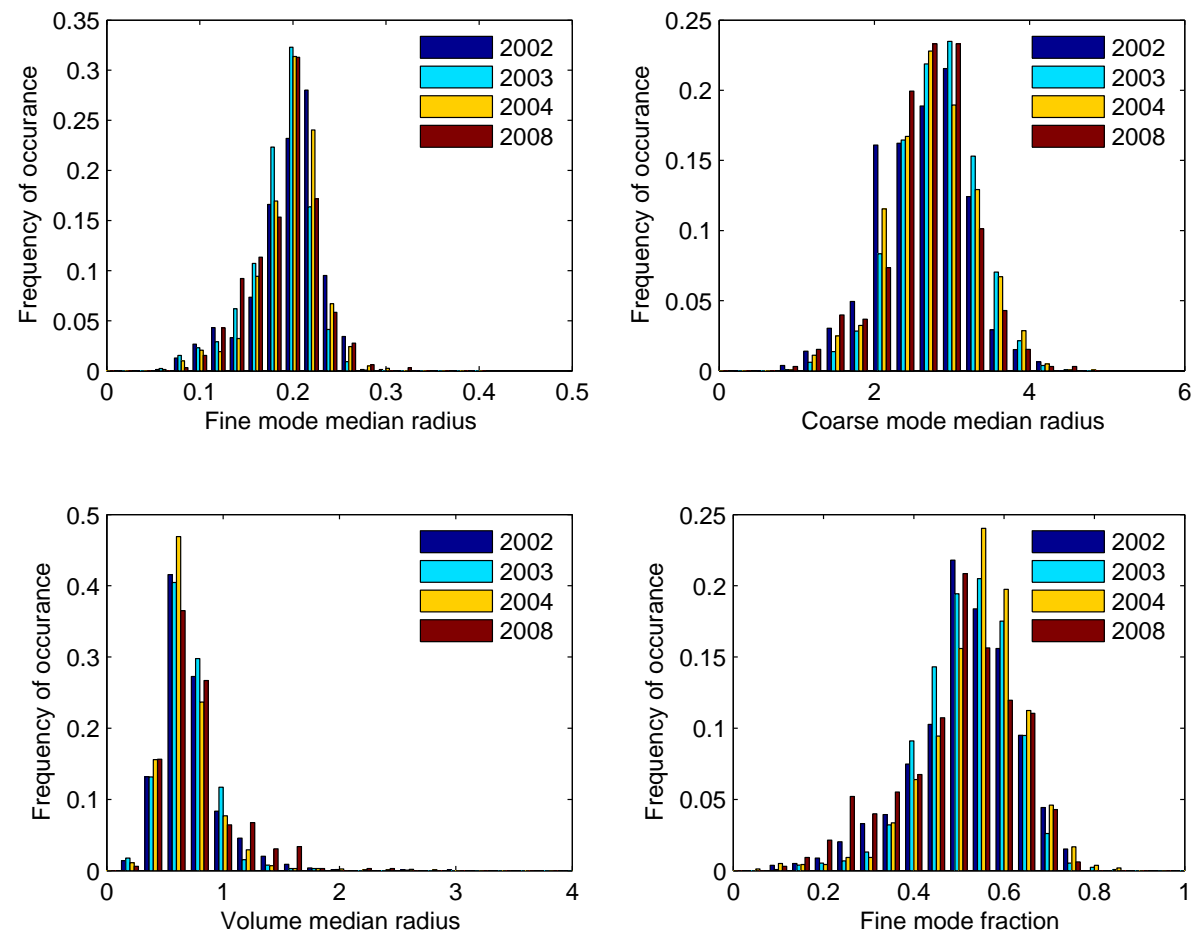

Fig. 6. Frequency of occurences of the fine mode median radius, coarse mode median radius, the whole spectra median mode and the fine mode mode volume fraction.

volume fraction is higher than those found in remote coastal sites $(\sim 20 \%-30 \%)$, where maritime aerosol dominates and urban-industrial aerosols have less influence (Smirnov et al., 2003). It is a little lower than the biomass burning aerosols found in Zambia $(\sim 57 \%)$ and close to those urban-industrial types found in Mexico City (Dubovik et al., 2002).

Figure 6 shows the frequency distribution information of the annual aerosol size distributions. The radius bin intervals of frequency distributions for the fine, coarse and the whole spectra are $0.02,0.3$ and $0.2 \mu \mathrm{m}$ respectively. The bin interval of fine mode volume fraction is 0.05 . Both the fine and coarse median radiuses show a skewed normal distribution with peak values occurring towards the larger radius. The modal values of median radius are around $0.2,3$ and $0.6 \mu \mathrm{m}$ for the fine, coarse and the whole modes respectively. The percentages of fine mode volume fraction larger than 0.5 are $61 \%, 61 \%, 70 \%$ and $54 \%$ for each year respectively, showing that the fine mode aerosols dominate in local atmosphere. The wide geometric standard deviation of fine mode volume fraction implies the large local atmospheric aerosol variation.

The frequency distributions of AOD and Angstrom exponent are shown in Figs. 8 and 9 respectively. The bin intervals for the AOD and Angstrom exponent are 0.2 and 0.1 respectively. It is found that the aerosol optical depth can be better characterized using a lognormal distribution (O'Neill et al., 2000). Our data confirms this point. When using a linear scale, the frequency distributions of AODs are generally uni- modal like some other urban-industrial aerosols (Singh et al., 2004 ) rather than bimodal. The modal values are $\sim 0.3$. The occurrence of high aerosol loading with AOD $>0.7$ are 0.34 , $0.34,0.58$ and 0.21 for each year respectively, and the annual average highest AODs and aerosol volume concentrations are found in 2004. The Angstrom exponents have modal values of $\sim 0.5$. It is skewed towards high Angstrom exponent, indicating the more fine aerosols. The Angstrom exponent has a relatively large width with the geometric standard deviations of $\sim 0.2$ with a modal value larger than 1 , which is larger than those predominately coarse aerosols coastal regions (Smirnov et al., 2002). It indicates the Angstrom exponent has a dependence on the spectral AODs rather than has a neutral relationship. Because coarse aerosols scatter and absorb less than fine aerosols, a predominately coarse aerosol environment would has the Angstrom exponent less dependent on the AOD channel range. This indicates fine aerosols play an important role in local environment.

\subsection{Size distribution under different atmospheric con- ditions}

Aerosol has a lifetime or around 5-10 days in the atmosphere and its physical and chemical properties would change with time. However, its evolution process and mechanism are not clearly understood. Therefore much attention has been focused on studying aerosol properties on different conditions 

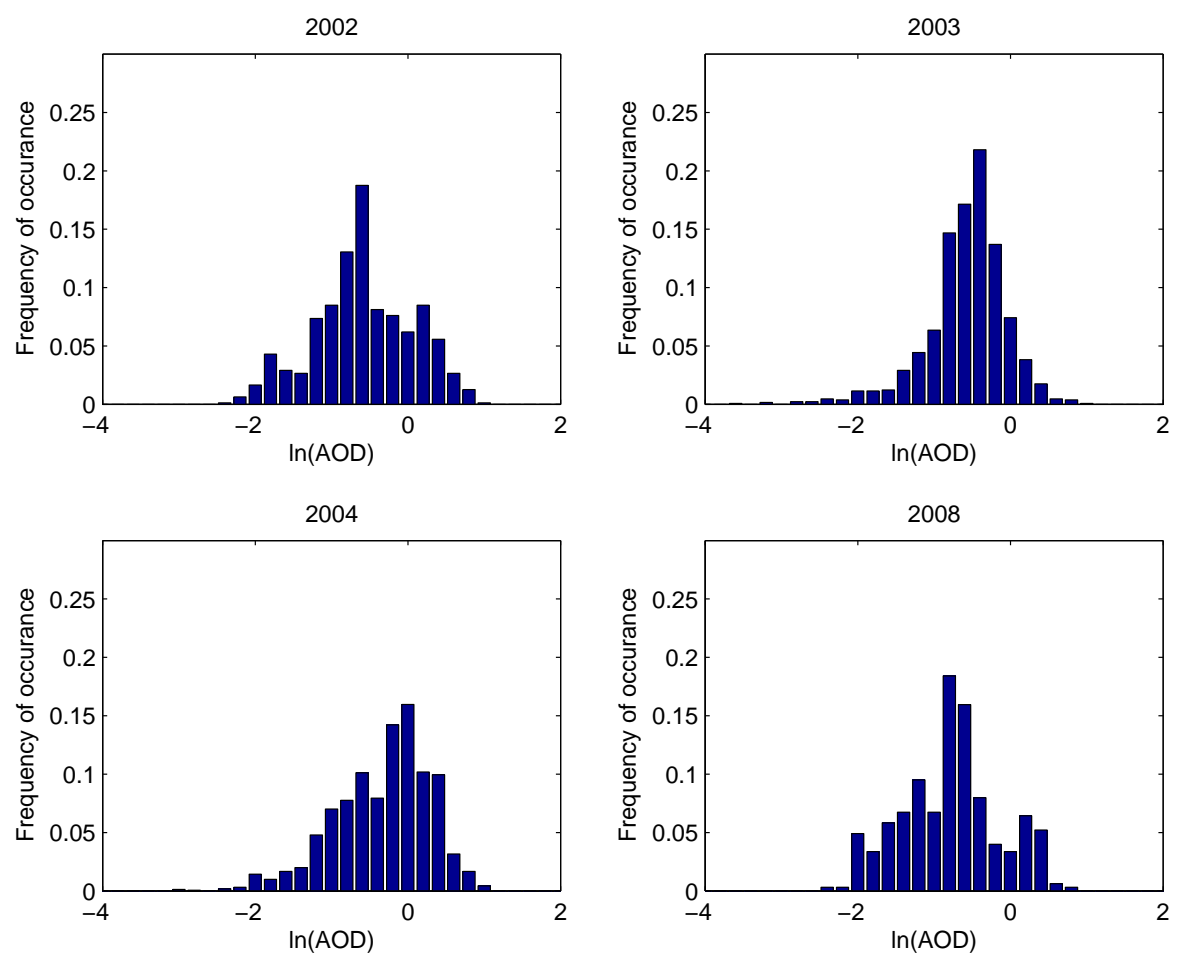

Fig. 7. Frequency of occurrences of AODs in the years of 2002, 2003, 2004 and 2008.
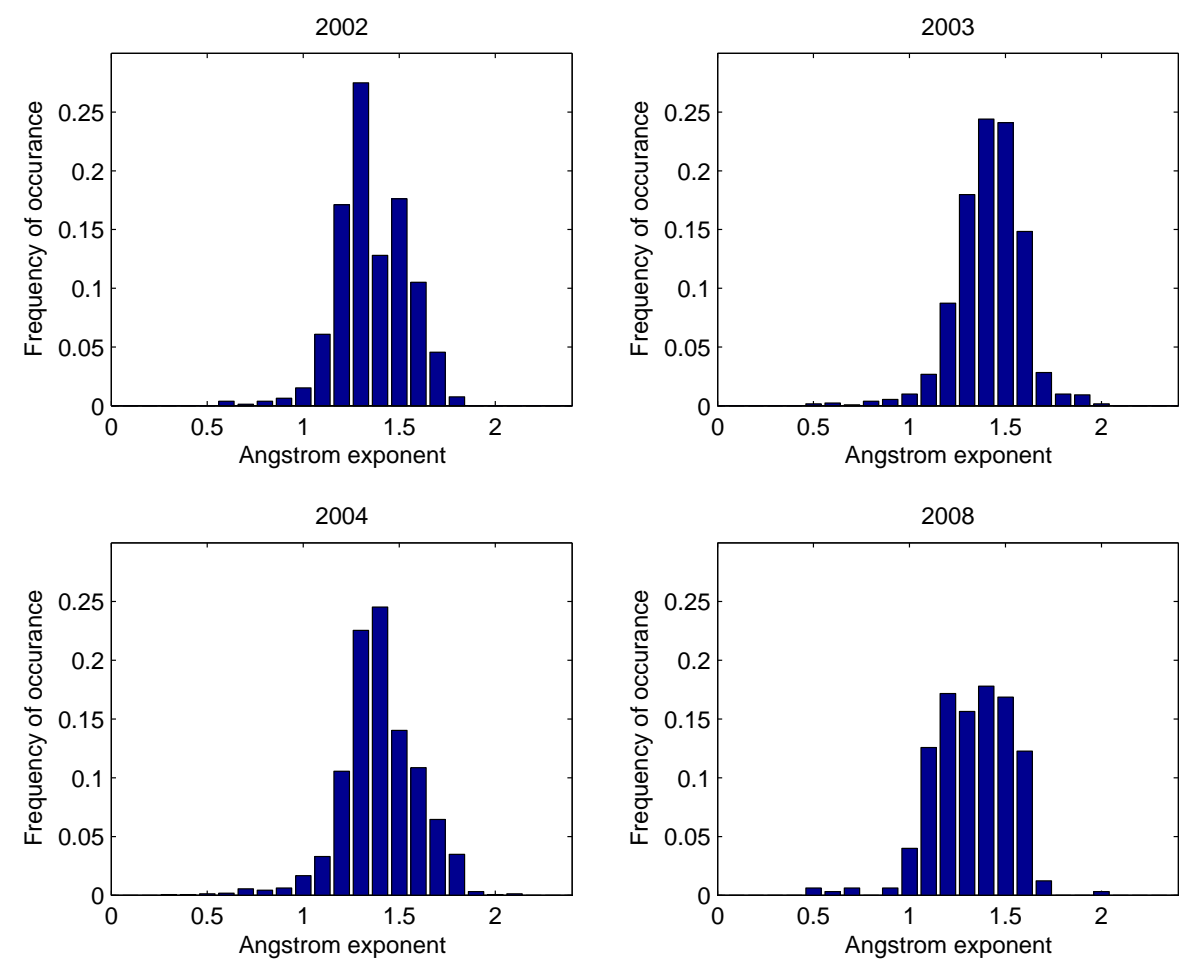

Fig. 8. Frequency of occurrences of Angstrom exponent in the years of 2002, 2003, 2004 and 2008. 

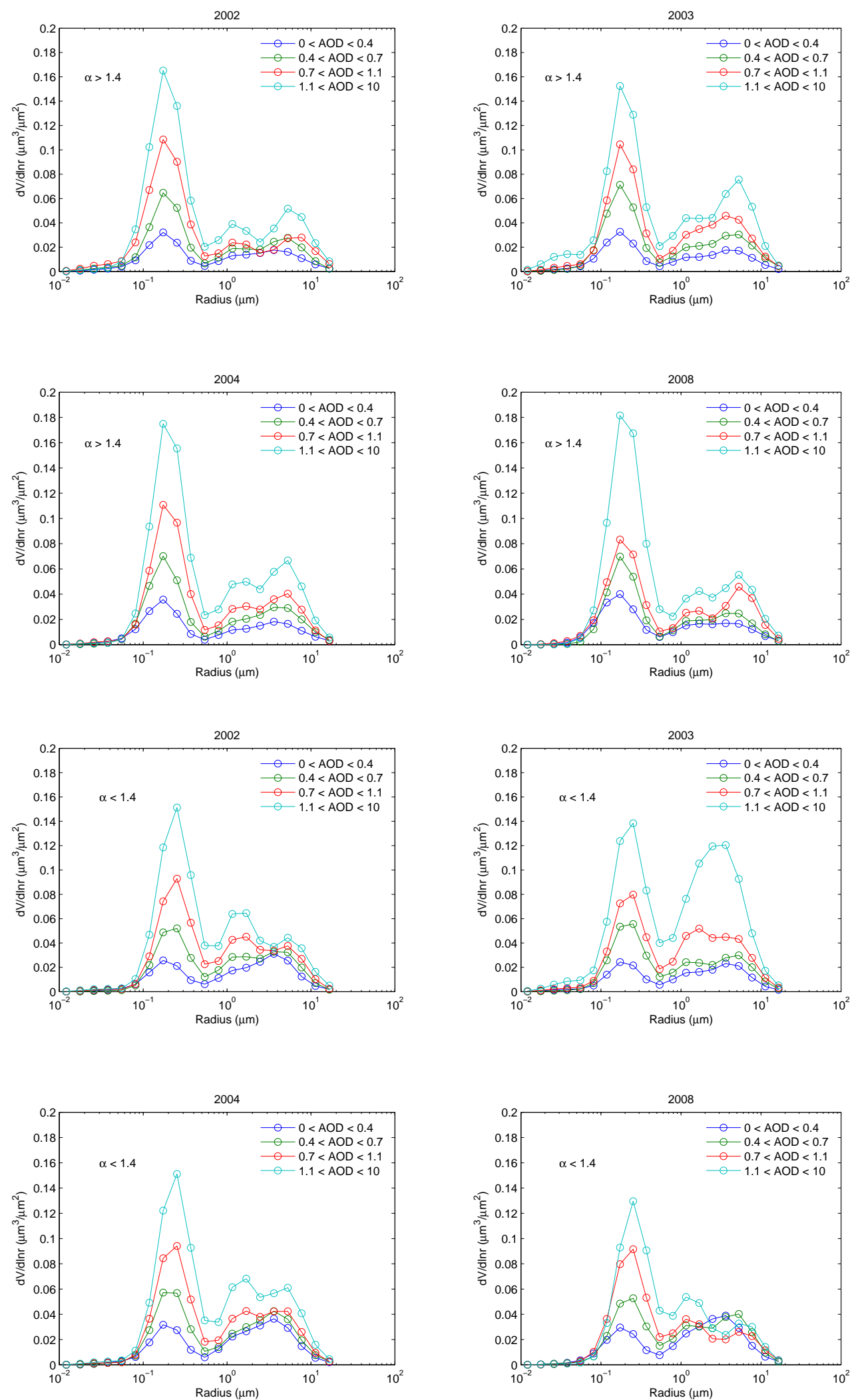

Fig. 9. Aerosol size distributions in different AOD bins of $\alpha>1.4$ (upper plots) and $\alpha<1.4$ (lower plots). 
like its size distribution evolution under different loadings to investigate aerosol evolution processes such as the aerosol hygroscopic growth, coagulation and aging. Schafer et al. (2008) examined the Amazon aerosol size distributions under different aerosol optical depth and found decreasing coarse aerosols with increasing optical depth. Eck et al. (2005) studied the size distributions under different aerosol optical depths in eastern Asia, and found a systematic shift of aerosol size distribution including the volume fraction, median radius and width, which is partially attributed to aerosol hygroscopic growth. The predominately fine and coarse events at different sites of Arabia Gulf were investigated (Eck et al., 2008), where larger fine mode median radius is found under heavy pollution days with higher aerosol loading and larger Angstrom exponent. By comparing the inland and desert sites the cause is attributed to aerosol hygroscopic growth under more humid marine environment.

Figure 9 shows the size distributions under different aerosol loadings for each year with AODs bins of 0-0.4, 0.4$0.7,0.7-1.1$ and 1.1-10. The average measurement numbers are larger than 30 for each bin. For further discrimination, two different Angstrom exponents ranges are used to represent the predominately fine ( $\alpha>1.4$, upper plots) and more coarse mode ( $\alpha<1.4$, lower plots) conditions. It should be noted that the fine mode aerosol contributes a large volume fraction for both cases $(\alpha<1.4$ and $\alpha>1.4)$, indicating high fine mode aerosols in the local atmosphere. Using two Angstrom exponent ranges, the whole data can be utilized and there are sufficient qualified data numbers for the two cases since 1.4 is close to the median value according to the frequency occurrence distribution of Angstrom exponent. In fact, Angstrom exponent has been widely used to discriminate fine and coarse aerosols, where a predominately fine aerosol size distribution like urban pollution and biomass burnings generally corresponds to a high Angstrom exponent, while more coarse aerosols like sea salt and dust accompany with a low Angstrom exponent. Eck et al. (2008) studied the desert aerosol size distribution and discriminate the fine and coarse dominated events using $\alpha>0.7$ and $\alpha<0.7$ respectively. The fine or background maritime aerosol size distribution is investigated by Smirnov et al. (2003) using $\alpha<1$ as the threshold, while Kaufman et al. (2001) found the baseline/background maritime aerosols are with a small Angstrom exponent ranging from 0.77 to 1.1 over oceans.

When the Angstrom exponent is larger than 1.4 as shown in Fig. 9a, the predominately fine mode is more pronounced in comparison to Fig. $9 \mathrm{~b}$ with $\alpha<1.4$. As the AODs increase, both the fine and coarse aerosol concentrations go up. The fine mode volume fraction is found to have an increasing trend with AODs increasing, therefore the absolute fine mode volume increments is larger than that of the coarse mode. It implies the increasing of AODs is mainly due to the fine mode. For instance, the fine mode volume fraction in 2002 increases from $49 \%$ to $63 \%$ when $\alpha>1.4$. Because the fine mode volume fraction is the ratio of fine mode aerosol vol- ume concentration to the coarse mode aerosol volume concentration $\left(C_{f} / C_{V}\right)$, the increment of fine mode aerosol concentration is found be larger than that of the coarse mode aerosols when both the two modes are increasing. When $\alpha<1.4$, the fine mode volume fraction in the same year of 2002 increases from $37 \%$ to $56 \%$. The absolute fine mode volume fraction is larger under larger Angstrom exponent. Under low aerosol loadings or clean atmospheric conditions $(0<\mathrm{AOD}<0.4)$, both the fine and coarse modes are of low concentrations less than $0.5 \mu \mathrm{m}^{3} \mu \mathrm{m}^{-2}$, with a small fine mode volume fraction. The aerosol size distributions under low aerosol loading conditions resemble the background maritime aerosols found by others (Kaufman et al., 2001; Smirnov et al., 2000, 2003, e.g.,). The aerosol median radius and geometric standard deviation vary with AODs, but no obviously trend is found. The intercomparison between different years does not show significant difference.

When the aerosol loadings are higher, e.g., AOD exceeding 1 , a third mode appears with its peak centering at $\sim 1-$ $2 \mu \mathrm{m}$ between the fine and coarse modes. It is more significant for predominately fine mode aerosols with $\alpha>1.4$ than high coarse aerosol conditions with $\alpha<1$.4. Furthermore, it becomes more pronounced with higher aerosol concentrations as AODs increases. It implies that the third mode has a dependence on high aerosol loadings especially fine mode aerosols. Moreover, this third mode is found to appear throughout the season from July to November. This phenomenon has been observed by others. Singh et al. (2004) studied the aerosols in an industrial city in India and found a similar middle mode $\sim 1-2 \mu \mathrm{m}$ which is attributed to the hygroscopic growth of finer aerosols. Dubovik et al. (2002) studied aerosols in worldwide sites and found the growth of fine mode aerosol median radius with increasing optical depth. The aerosol hygroscopic growth was attributed as one of the most important mechanisms, and some other processes like the aerosol coagulation and aging process were also considered as possible reasons. Studies of the biomass burning aerosols in Africa (Eck et al., 2001, 2003b) and Brazil (Eck et al., 2003a; Reid et al., 1998, 1999) also show such radius increase of fine mode aerosol, where the aerosol aging, hygroscopic growth and mixing with urban aerosols have been considered as possible causes.

The average relative humidity in Hong Kong from July to November is usually higher than $70 \%$. Baumgardner et al. (2000) studied the urban aerosol in Mexican City and assumed that the aerosol becomes hydrated when relative humidity is greater than $60 \%$. The humid environment is likely to facilitate the aerosol hygroscopic growth and coagulation especially under high aerosol loadings. The pronounced organic aerosol increasing in the 0.49 to $2.5 \mu \mathrm{m}$ range has been found in September and October when the atmospheric environment is very humid (Zheng et al., 2008). It needs to be denoted that aerosol coagulation could also play an important role in the formation of the third mode. The shifting of fine mode aerosol growth towards larger size under higher aerosol 
loadings is observed in the urban-industrial areas like Mexican City by Dubovik et al. (2002), which are attributed to the aerosol hygroscopic growth and coagulation, but it was also specified that the shifting under higher aerosol loadings with low relative humidity (50-60\%) are observed on urban and biomass burning sites and therefore that the high relative humidity is not a necessarily primary factor. Furthermore, the local atmospheric conditions are impacted by the continental industrial outflow from the mainland of China (Cheng et al., 2006; Wang et al., 2003). The urban-industrial aerosol and its aging during the transport could have contributed to such phenomenon. The biomass burning aerosols from the continental outflow also have an impact on Hong Kong (Chan et al., 2000, 2003; Heald et al., 2003). Overall, the hygroscopic growth of urban-industrial aerosols and coagulation are the main causes for the appearance of the third mode considering the prevailing southern and eastern monsoon in this period, when the impact of biomass burning is relatively weak compared to other seasons.

Figure 10 shows the size distributions of different Angstrom exponents under two aerosol loadings, light $(\mathrm{AOD}<0.5)$ in the upper plot and heavy $(\mathrm{AOD}>0.5)$ in the lower plot, respectively. There are at least 30 measurements for each bin. A systematic trend of aerosol size distribution parameters shifting with the Angstrom exponent is observed under both low and high aerosol loading conditions. The fine mode volume fraction and geometric standard deviation increase with the $\alpha$ increasing, while the median radius decreases with higher $\alpha$. For instance, when AOD $>0.5$ in 2008 the fine mode volume fraction and geometric standard deviation increasing from $52.76 \%$ to $57.61 \%$ and 1.34 to $1.53 \mu \mathrm{m}$ respectively with $\alpha$ increasing (from the blue line to the cyan line in the subplot), while the median radius decreases from 0.67 to $0.59 \mu \mathrm{m}$. Reid et al. (1998) also found the increasing of geometric standard deviation with decreasing median radius when studying the biomass burning aerosol in Brazil. When further examining the fine and coarse mode respectively, it is found that the fine mode median radius shifts to smaller size while coarse mode median radius increases slightly when $\alpha$ increases. Their geometric standard deviations do not have an obvious trend. Here from our data similar changing exists. The fine mode median radius decreases from $0.193,0.195,0.195$ and $0.183 \mu \mathrm{m}$ to $0.163,0.151$, 0.150 and $0.158 \mu \mathrm{m}$ when $\mathrm{AOD}>0.5$ in the fours years respectively as shown in the upper subplots of Fig. 10 from the blue line to the cyan line, meanwhile the coarse mode median radius increases from 2.576, 2.355, 2.632 and $2.467 \mu \mathrm{m}$ to $3.038,2.945,2.919$ and $2.830 \mu \mathrm{m}$ respectively.

The systematic shift shows the close correlation of Angstrom exponent with the aerosol size distribution especially the fine mode. The bimodal aerosol size distribution is closely correlated to the Angstrom exponent (Kaufman, 1993; O'Neill et al., 2001, 2003). The fine mode has impact on the Angstrom exponent, where larger fine mode volume fraction and smaller fine mode median size tends to corre- spond to a high Angstrom exponent (Schuster et al., 2006). The results shown here agree well with those works. This is mainly due to the physical mechanism that fine aerosols interact more with visible wavelength while coarse aerosols have much more impact on the near infrared wavelength. Therefore the increasing of fine aerosols results in more scattering and absorption especially in the short wavelength channels and lead to higher Angstrom exponent. Furthermore, the sea salt contributing greatly to local coarse aerosols causes weaker interacting with longer wavelength channels than other coarse dusts due to its weak absorbing ability. Therefore, variation of coarse mode has less effect on scattering and absorbing light and therefore cause less changing to the Angstrom exponent compared to the effect of the fine mode.

The main difference between low and high aerosol loadings are that under the high aerosol loading condition $(\mathrm{AOD}>0.5)$, the fine volume fraction is higher with larger median radius, compared to the low aerosol loadings $(\mathrm{AOD}<0.5)$. For instance, the 2004 has the fine volume fraction, geometric standard deviation and median radius ranging 50.42-62.22\%, $1.26-1.54 \mu \mathrm{m}$ and $0.52-0.75 \mu \mathrm{m}$ respectively when AOD $>0.5$, while they are 28.85-56.37\%, 1.30$1.58 \mu \mathrm{m}$ and $0.56-1.29 \mu \mathrm{m}$ respectively with $\mathrm{AOD}<0.5$. The absolute variation of those parameters is smaller under high AOD condition. Comparing Fig. 10a and b, it is observed that under high aerosol loadings $(\mathrm{AOD}>0.5)$ the absolute fine mode concentrations remains more or less the same with increasing $\alpha$, while the coarse mode concentration increase more significantly. Under low aerosol loading $(\mathrm{AOD}<0.5)$, the fine mode decreases significantly as $\alpha$ increases with increasing coarse mode. For instance, the fine mode volume fractions are $52.76 \%, 52.90 \%, 58.57 \%$ and $57.61 \%$ as the AOD bin increases when AOD $>0.5$, while they increase as $34.46 \%, 41.96 \%, 53.42 \%$ and $62.95 \%$ when $\mathrm{AOD}>0.5$.

The third mode is more pronounced with higher Angstrom exponent under high AODs. It is not significant under low AODs although the coarse mode has a higher mode volume fraction. For instance, according to Fig. 10 the coarse modes are smaller than $0.04 \mu \mathrm{m}^{3} \mu \mathrm{m}^{-2}$ at $1.0<\alpha<1.2$ when $\mathrm{AOD}<0.5$ in 2004 , while the third mode exceeds $0.06 \mu \mathrm{m}^{3} \mu \mathrm{m}^{-2}$ at $1.0<\alpha<1.2$ when $\mathrm{AOD}>0.5$ in the same year. The occurrence of the third mode seems to have a dependence on enough fine mode aerosols. On the other hand, when $\mathrm{AOD}<0.5$ the coarse mode aerosols would increase when Angstrom exponent decreases and these coarse mode aerosols increment are mainly those coarse aerosols with radius $(r>3 \mu \mathrm{m})$ larger than the third mode $(1-2 \mu \mathrm{m})$. It indicates in another way that the third mode does not depend on the coarse aerosol increment and helps correctly understand the aerosol composition since some accumulation sea salt is also described as having a radius $\sim 1-2 \mu \mathrm{m}$ (Hess et al., 1998). 

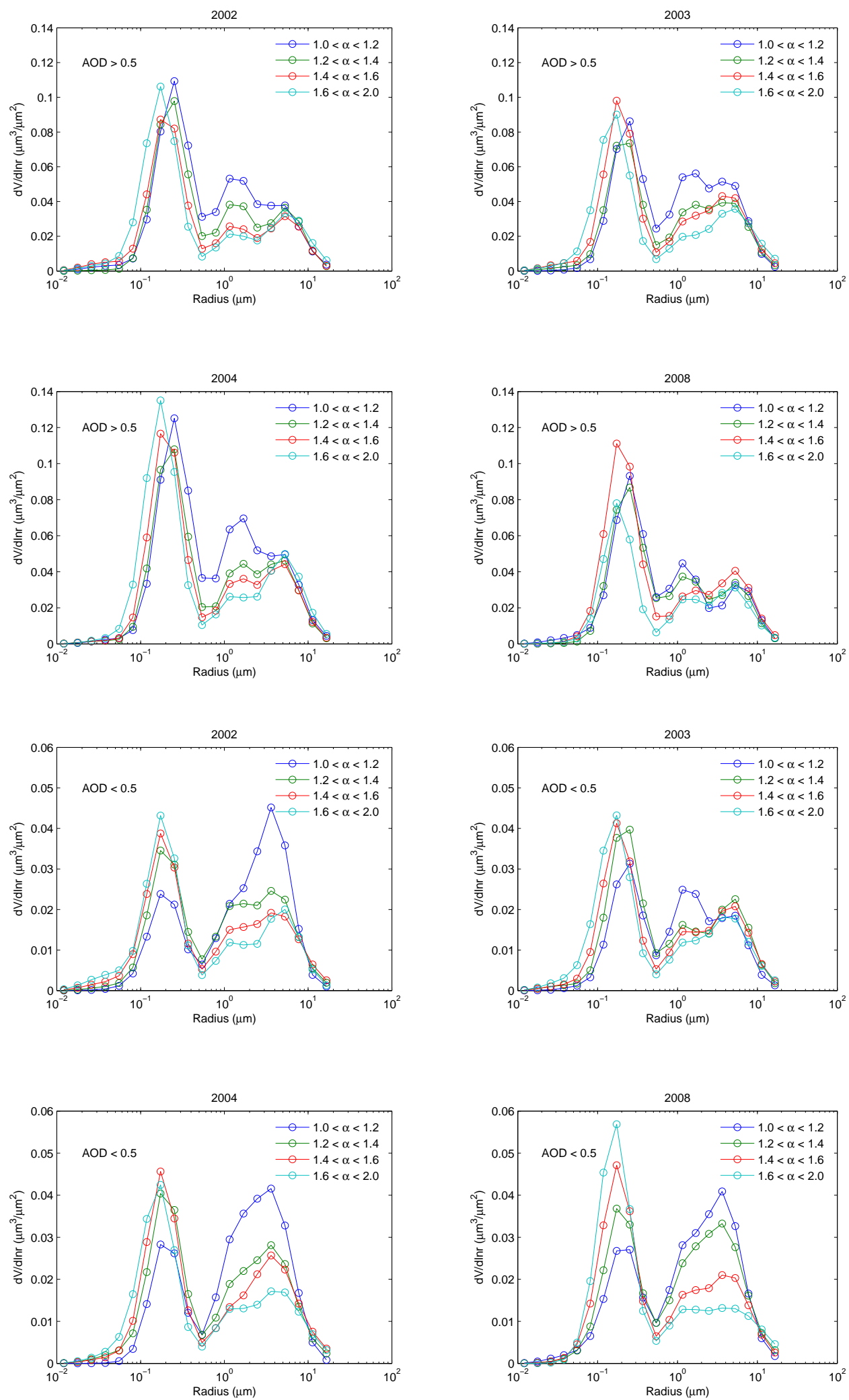

Fig. 10. Aerosol size distributions in different Angstrom exponent bins of AOD $>0.5$ (upper plots) and AOD $<0.5$ (lower plots). 


\section{Conclusions}

Observations of columnar aerosols in Hong Kong have been performed using a sun-sky radiometer. The study focuses on investigation of the aerosol size distribution and help understand the local aerosol properties, evolution, hygroscopic growth and coagulation.

Data are compared with the MODIS and AERONET dataset. The ground-measured AODs and MODIS AODs have a correlation coefficient of 0.93 , and the aerosol volume size distribution compared with that of the local AERONET shows agreement. A bimodal structure of local aerosol size distribution is found. The fine mode generally has a radius range from 0.01 to $0.6 \mu \mathrm{m}$ with a median volume radius of $\sim 0.2 \mu \mathrm{m}$, and the coarse mode locates from 0.6 to $16 \mu \mathrm{m}$ with a median radius of $\sim 3 \mu \mathrm{m}$. They contribute more or less the same volume mode volume fraction. The annual average Angstrom exponent is $\sim 1.3$ with average AOD 0.6. It indicates both fine aerosols from local emission or continental transport and coarse aerosols like sea salt from the ocean play an important role in composing atmospheric aerosols in Hong Kong. The frequency distributions of fine mode mode volume fraction and Angstrom exponent skews towards high values, indicating more fine mode aerosols. Intercomparison of those aerosol parameters in different years show no significant trend, but a moderate increasing of fine mode volume fraction could be observed. The local aerosol size distribution resembles those found in some other urban-industrial areas and those of a coastal environment.

The variation of aerosol size distribution under different atmospheric conditions has been investigated. A systematic shift of size distribution parameters is found under different aerosol loadings and Angstrom exponents. High aerosol loading and large Angstrom exponent tends to coincide with more fine mode aerosols. The aerosol size distribution parameters shift with Angstrom exponent. As Angstrom exponent increases, the fine mode mode volume fraction and geometric standard deviation increase as well, while the median radius has an opposite trend. Furthermore, it is found that fine mode is more closely correlated with Angstrom exponent than the coarse mode, where increasing Angstrom exponent corresponds to decreasing fine mode median radius. This agrees with other's works. The physics that more fine aerosols result in more scattering and absorbing in the visible wavelengths that it interacts with the longer wavelength channels and lead to higher Angstrom exponent. Furthermore, under predominately fine aerosol event $(\alpha>0.7)$, it is found that the coarse mode variation with $\alpha$ is significant while the fine mode remains more or less the same. When it is the high coarse aerosol condition $(\alpha<0.7)$, both fine and coarse mode vary with $\alpha$ increasing, where they decrease and increase respectively. The hygroscopic growth of aerosols and aerosol coagulation are speculated to be the main underlying mechanism for the observed shifting.
A third mode is observed with its radius $\sim 1-2 \mu \mathrm{m}$. It is likely to appear under atmospheric conditions with high aerosol loadings and more fine mode aerosols. When the aerosol optical depth is lower than 0.5 , it is insignificant. It becomes especially pronounced when the aerosol loading and Angstrom exponent are larger than 1. The increasing of aerosol loadings leads to a more significant third mode. Under low aerosol loading conditions, the increasing coarse mode aerosols with decreasing Angstrom exponent are mainly from aerosol with radius larger than the third mode. The aerosol hygroscopic growth and coagulation are the main causes for such phenomenon. The high relative humidity during this period in Hong Kong and high fine mode aerosols in such urban-industrial area are likely to facilitate the aerosol hygroscopic growth. When aerosol concentrations and especially the fine mode aerosols are extremely high, aerosol coagulation might occur and produce many third mode aerosols. Nevertheless, the local aerosol mixing with transported aerosols like those aged aerosols might also has some impact and should not be neglected. It has to be pointed out that it is hard to fully understand the mechanisms for aerosol evolution when studying columnar atmospheric aerosol using remote sensing technology. It should be emphasized that the attribution of the observed aerosol size distribution variation and shifting to the aerosol hygroscopic growth and coagulation is speculation rather than confirmation. More works combining laboratory, sampling and modeling methods would help to understand the aerosol hygroscopic growth and coagulation.

Acknowledgements. The work described in this paper was fully supported by a grant from City University of Hong Kong (Project No. 7200109). We would like to thank the MODIS Science Data Support Team for processing MODIS data. We thank the Principal Investigators and their staff of the AERONET site, PolyU Hong Kong, for providing their valuable data. We thank reviewers very much for their valuable comments and suggestions.

Edited by: M. Van Roozendael

\section{References}

Andreae, M. O.: The dark side of aerosols, Nature, 409, 671-672, 2001.

Angstrom, A.: On the atmospheric transmission of Sun radiation and on dust in the air, Geogr. Ann., 11, 156-166, 1929.

Baumgardner, D., Raga, G. B., Kok, G., Ogren, J., Rosas, I., Baz, A., and Novakov, T.: On the evolution of aerosol properties at a mountain site above Mexico City, J. Geophys. Res., 105(D17), 22243-22253, 2000.

Boi, P., Tonna, G., Dalu, G., Nakajima, T., Olivieri, B., Pompei, A., Campanelli, M., and Rao, R.: Calibration and data elaboration procedure for sky irradiance measurements, Appl. Optics, 38, 896-907, 1999.

Campanelli, M., Estelles, V., Tomasi, C., Nakajima, T., Malvestuto, V., and Martinez-Lozano, J. A.: Application of the SKYRAD 
Improved Langley plot method for the in situ calibration of CIMEL Sun-sky photometers, Appl. Optics, 46, 2688-2702, 2007.

Carmine, C. D., Campanelli, M., Nakajima, T., Tomasi, C., and Vitale, V.: Retrievals of Antarctic aerosol characteristics using a Sun-sky radiometer during the 2001-2002 austral summer campaign, J. Geophys. Res., 110, D13202, doi:10.1029/ 2004JD005280, 2005.

Chan, C. Y., Chan, L. Y., Harris, J. M., Oltmans, S. J., Blake, D. R., Qin, Y., Zheng, Y. G., and Zheng, X. D.: Characteristics of biomass burning emission sources, transport, and chemical speciation in enhanced springtime tropospheric ozone profile over Hong Kong, J. Geophys. Res., 108, 4015, doi:10.1029/ 2001JD001555, 2003.

Chan, L., Chan, C., Liu, H., Christopher, S., Oltmans, S., and Harris, J.: A Case Study on the Biomass Burning in Southeast Asia and Enhancement of Tropospheric Ozone over Hong Kong, Geophys. Res. Lett., 27, 1479-1482, 2000.

Cheng, Y., Lee, S. C., Ho, K. F., Wang, Y. Q., Cao, J. J., Chow, J. C., and Watson, J. G.: Black carbon measurement in a coastal area of south China, J. Geophys. Res., 111, D12310, doi: 10.1029/2005JD006663, 2006.

Chu, D. A., Kaufman, Y. J., Zibordi, G., Chern, J. D., Mao, J., Li, C., and Holben, B. N.: Global monitoring of air pollution over land from the Earth Observing System-Terra Moderate Resolution Imaging Spectroradiometer (MODIS), J. Geophys. Res., 108, 4661, doi:10.1029/2002JD003179, 2003.

Cohen, D. D., Garton, D., Stelcer, E., Hawas, O., Wang, T., Poon, S., Kim, J., Choi, B. C., Oh, S. N., Shin, H.-J., Ko, M. Y., and Uematsu, M.: Multielemental analysis and characterization of fine aerosols at several key ACE-Asia sites, J. Geophys. Res., 109, D19S12, doi:10.1029/2003JD003569, 2004.

Dubovik, O. and King, M. D.: A flexible inversion algorithm for retrieval of aerosol optical properties from Sun and sky radiance measurements, J. Geophys. Res., 105, 20673-20696, 2000.

Dubovik, O., Holben, B. N., Eck, T. F., Smirnov, A., Kaufman, Y. J., King, M. D., Tanré, D., and Slutsker, I.: Variability of absorption and optical properties of key aerosol types observed in worldwide locations, J. Atmos. Sci., 59, 590-608, 2002.

Eck, T. F., Holben, B. N., Ward, D. E., Dubovik, O., Reid, J. S., Smirnov, A., Mukelabai, M. M., Hsu, N. C., O’Neill, N. T., and Slutsker, I.: Characterization of the optical properties of biomass burning aerosols in Zambia during the 1997 ZIBBEE field campaign, J. Geophys. Res., 106, 3425-3448, 2001.

Eck, T. F., Holben, B. N., Reid, J. S., O’Neill, N. T., Schafer, J. S., Dubovik, O., Smirnov, A., Yamasoe, M. A., and Artaxo, P.: High aerosol optical depth biomass burning events: A comparison of optical properties for different source regions, Geophys. Res. Lett., 30, 2035, doi:10.1029/2003GL017861, 2003a.

Eck, T. F., Holben, B. N., Ward, D. E., Mukelabai, M. M., Dubovik, O., Smirnov, A., Schafer, J. S., Hsu, N. C., Piketh, S. J., Queface, A., Roux, J. L., Swap, R. J., and Slutsker, I.: Variability of biomass burning aerosol optical characteristics in southern Africa during the SAFARI 2000 dry season campaign and a comparison of single scattering albedo estimates from radiometric measurements, J. Geophys. Res., 108, 8477, doi:10.1029/ 2002JD002321, 2003b.

Eck, T. F., Holben, B. N., Dubovik, O., Smirnov, A., Goloub, P., Chen, H. B., Chatenet, B., Gomes, L., Zhang, X.-Y., Tsay, S.-
C., Ji, Q., Giles, D., and Slutsker, I.: Columnar aerosol optical properties at AERONET sites in central eastern Asia and aerosol transport to the tropical mid-Pacific, J. Geophys. Res., 110, D06202, doi:10.1029/2004JD005274, 2005.

Eck, T. F., Holben, B. N., Reid, J. S., Sinyuk, A., Dubovik, O., Smirnov, A., Giles, D., O’Neill, N. T., Tsay, S.-C., Ji, Q., Mandoos, A. A., Khan, M. R., Reid, E. A., Schafer, J. S., Sorokine, M., Newcomb, W., and Slutsker, I.: Spatial and temporal variability of column-integrated aerosol optical properties in the southern Arabian Gulf and United Arab Emirates in summer, J. Geophys. Res., 113, D01204, doi:10.1029/2007JD008944, 2008.

Heald, C. L., Jacob, D. J., Palmer, P. I., Evans, M. J., Sachse, G. W., Singh, H. B., and Blake, D. R.: Biomass burning emission inventory with daily resolution: Application to aircraft observations of Asian outflow, J. Geophys. Res., 108, 8811, doi: 10.1029/2002JD003082, 2003.

Hess, M., Koepke, P., and Schult, I.: Optical properties of aerosols and clouds: The software package OPAC, B. Am. Meteorol. Soc., 79, 831-844, 1998.

Highwood, E. J., Haywood, J. M., Silverstone, M. D., Newman, S. M., and Taylor, J. P.: Radiative properties and direct effect of Saharan dust measured by the C-130 aircraft during Saharan Dust Experiment (SHADE): 2. Terrestrial spectrum, J. Geophys. Res., 108, 8578, doi:10.1029/2002JD002552, 2003.

Holben, B. N., Eck, T. F., Slutsker, I., Tanré, D., Buis, J. P., Setzer, A., Vermote, E., Reagan, J. A., Kaufman, Y. J., Nakajima, T., Lavenu, F., Jankowiak, I., and Smirnov, A.: AERONET-A federated instrument network and data archive for aerosol characterization, Remote Sens. Environ., 66, 1-16, 1998.

Holben, B. N., Tanré, D., Smirnov, A., Eck, T. F., Slutsker, I., Abuhassan, N., Newcomb, W. W., Schafer, J. S., Chatenet, B., Lavenu, F., Kaufman, Y. J., Castle, J. V., Setzer, A., Markham, B., Clark, D., Frouin, R., Halthore, R., Karneli, A., O’Neill, N. T., Pietras, C., Pinker, R. T., Voss, K., and Zibordi, G.: An emerging ground-based aerosol climatology: Aerosol optical depth from AERONET, J. Geophys. Res., 106, 12067-12097, 2001.

Huebert, B. J., Bates, T., Russell, P. B., Shi, G., Kim, Y. J., Kawamura, K., Carmichael, G., and Nakajima, T.: An overview of ACE-Asia: Strategies for quantifying the relationships between Asian aerosols and their climatic impacts, J. Geophys. Res., 108, 8633, doi:10.1029/2003JD003550, 2003.

Ichoku, C., Chu, D. A., Mattoo, S., Kaufman, Y. J., Remer, L. A., Tanré, D., Slutsker, I., and Holben, B. N.: A spatiotemporal approach for global validation and analysis of MODIS aerosol products, Geophys. Res. Lett., 29, 8006, doi:10.1029/ 2001GL013206, 2002.

Intergovernmental Panel on Climate Change: Climate Change 2007: The Physical Science Basis, Cambridge Univ. Press, Cambridge, UK, 2007.

Kaufman, Y. J.: Aerosol Optical Thickness and Atmospheric Path Radiance, J. Geophys. Res., 98, 2677-2692, 1993.

Kaufman, Y. J., Gitelson, A., Karnieli, A., Ganor, E., Fraser, R. S., Nakajima, T., Mattoo, S., and Holben, B. N.: Size distribution and scattering phase function of aerosol particles retrieved from sky brightness measurements, J. Geophys. Res., 99, 1034110356, 1994.

Kaufman, Y. J., Tanré, D., Remer, L. A., Vermote, E. F., Chu, A., and Holben, B. N.: Operational remote sensing of tropospheric 
aerosol over land from EOS moderate resolution imaging spectroradiometer, J. Geophys. Res., 102, 17051-17067, 1997.

Kaufman, Y. J., Smirnov, A., Holben, B. N., and Dubovik, O.: Baseline Maritime Aerosol: Methodology to Derive the Optical Thickness and Scattering Properties, Geophys. Res. Lett., 28, 3251-3254, 2001.

Kaufman, Y. J., Tanré, D., and Boucher, O.: A satellite view of aerosols in the climate system, Nature, 419, 215-223, 2002.

Kaufman, Y. J., Boucher, O., Tanré, D., Chin, M., Remer, L. A., and Takemura, T.: Aerosol anthropogenic component estimated from satellite data, Geophys. Res. Lett., 32, L17804, doi:10. 1029/2005GL023125, 2005.

Kim, D.-H., Sohn, B.-J., Nakajima, T., Takamura, T., Takemura, T., Choi, B.-C., and Yoon, S.-C.: Aerosol optical properties over east Asia determined from ground-based sky radiation measurements, J. Geophys. Res., 109, D02209, doi:10.1029/ 2003JD003387, 2004.

Kleidman, R. G., O’Neill, N. T., Remer, L. A., Kaufman, Y. J., Eck, T. F., Tanré, D., Dubovik, O., and Holben, B. N.: Comparison of Moderate Resolution Imaging Spectroradiometer (MODIS) and Aerosol Robotic Network (AERONET) remote-sensing retrievals of aerosol fine mode fraction over ocean, J. Geophys. Res., 110, D22205, doi:10.1029/2005JD005760, 2005.

Levy, R. C., Remer, L. A., Mattoo, S., Vermote, E. F., and Kaufman, Y. J.: Second-generation operational algorithm: Retrieval of aerosol properties over land from inversion of Moderate Resolution Imaging Spectroradiometer spectral reflectance, J. Geophys. Res., 112, D13211, doi:10.1029/2006JD007811, 2007.

Nakajima, T., Tonna, G., Rao, R. Z., Boi, P., Kaufman, Y. J., and Holben, B. N.: Use of sky brightness measurements from ground for remote sensing of particulate polydispersions, Appl. Optics, 35, 2672-2686, 1996.

Nakajima, T., Sekiguchi, M., Takemura, T., Uno, I., Higurashi, A., Kim, D., Sohn, B. J., Oh, S.-N., Nakajima, T. Y., Ohta, S., Okada, I., Takamura, T., and Kawamoto, K.: Significance of direct and indirect radiative forcings of aerosols in the East China Sea region, J. Geophys. Res., 108, 8658, doi:10.1029/2002JD003261, 2003.

O’Neill, N. T., Ignatov, A., Holben, B. N., and Eck, T. F.: The Lognormal Distribution as a Reference for Reporting Aerosol Optical Depth Statistics; Empirical Tests Using Multi-Year, MultiSite AERONET Sunphotometer Data, Geophys. Res. Lett., 27, 3333-3336, 2000.

O’Neill, N. T., Eck, T. F., Holben, B. N., Smirnov, A., Dubovik, O., and Royer, A.: Bimodal size distribution influences on the variation of Angstrom derivatives in spectral and optical depth space, J. Geophys. Res., 106, 9787-9806, 2001.

O’Neill, N. T., Eck, T. F., Smirnov, A., Holben, B. N., and Thulasiraman, S.: Spectral discrimination of coarse and fine mode optical depth, J. Geophys. Res., 108, 4559, doi:10.1029/2002JD002975, 2003.
Reid, J. S., Hobbs, P. V., Ferek, R. J., Blake, D. R., Martins, J. V., Dunlap, M. R., and Liousse, C.: Physical, chemical, and optical properties of regional hazes dominated by smoke in Brazil, J. Geophys. Res., 103, 32059-32080, 1998.

Reid, J. S., Eck, T. F., Christopher, S. A., Hobbs, P. V., and Holben, B. N.: Use of the Angstrom exponent to estimate the variability of optical and physical properties of aging smoke particles in Brazil, J. Geophys. Res., 104, 27473-27489, 1999.

Remer, L. A., Kaufman, Y. J., Tanré, D., Mattoo, S., Chu, D. A., Martins, J. V., Li, R. R., Ichoku, C., Levy, R. C., Kleidman, R. G., Eck, T. F., Vermote, E., and Holben, B. N.: The MODIS aerosol algorithm, products, and validation, J. Atmos. Sci., 62, 947-973, 2005.

Schafer, J. S., Eck, T. F., Holben, B. N., Artaxo, P., and Duarte, A. F.: Characterization of the optical properties of atmospheric aerosols in Amazonia from long-term AERONET monitoring (1993-1995 and 1999-2006), J. Geophys. Res., 113, D04204, doi:10.1029/2007JD009319, 2008.

Schuster, G. L., Dubovik, O., and Holben, B. N.: Angstrom exponent and bimodal aerosol size distributions, J. Geophys. Res., 111, D07207, doi:10.1029/2005JD006328, 2006.

Singh, R. P., Dey, S., Tripathi, S. N., Tare, V., and Holben, B.: Variability of aerosol parameters over Kanpur, northern India, J. Geophys. Res., 109, D23206, doi:10.1029/2004JD004966, 2004.

Smirnov, A., Holben, B. N., Eck, T. F., Dubovik, O., and Slutsker, I.: Cloud-screening and quality control algorithms for the AERONET database, Remote Sens. Environ., 73, 337-349, 2000.

Smirnov, A., Holben, B. N., Kaufman, Y. J., Dubovik, O., Eck, T. F., Slutsker, I., Pietras, C., and Halthore, R. N.: Optical Properties of Atmospheric Aerosol in Maritime Environments, J. Atmos. Sci., 59, 501-523, 2002.

Smirnov, A., Holben, B. N., Dubovik, O., Frouin, R., Eck, T. F., and Slutsker, I.: Maritime component in aerosol optical models derived from Aerosol Robotic Network data, J. Geophys. Res., 108, 4033, doi:10.1029/2002JD002701, 2003.

Tang, I. N.: Chemical and size effects of hygroscopic aerosols on light scattering coefficients, J. Geophys. Res., 101, 1924519250, 1996.

Tonna, G., Nakajima, T., and Rao, R.: Aerosol Features Retrieved from Solar Aureole Data - a Simulation Study Concerning a Turbid Atmosphere, Appl. Optics, 34, 4486-4499, 1995.

Wang, T., Ding, A. J., Blake, D. R., Zahorowski, W., Poon, C. N., and Li, Y. S.: Chemical characterization of the boundary layer outflow of air pollution to Hong Kong during February-April 2001, J. Geophys. Res., 108, 8787, doi:10.1029/2002JD003272, 2003.

Zheng, M., Kester, D. R., Wang, F., Shi, X., and Guo, Z.: Size distribution of organic and inorganic species in Hong Kong aerosols during the wet and dry seasons, J. Geophys. Res., 113, D16303, doi:10.1029/2007JD009494, 2008. 